\title{
Inoculation of rhizobia increases lima bean (Phaseolus lunatus) yield in soils from Piauí and Ceará states, Brazil ${ }^{1}$
}

\author{
Claudyanne do Nascimento Costa2, Jadson Emanuel Lopes Antunes², Angela Celis de Almeida Lopes ${ }^{3}$, \\ Ana Dolores Santiago de Freitas ${ }^{4}$, Ademir Sérgio Ferreira Araujo ${ }^{2 *} \mathbb{0}$
}

$10.1590 / 0034-737 X 202067050010$

\begin{abstract}
The inoculation of rhizobia in lima bean can increase its yield and contribute to smallholder farms. In this study, the potential of rhizobia in increasing the lima bean yield was evaluated in two regions from Piaui and Ceará states. The experiments were conducted in field comparing three rhizobia strains (UFPI32, UFPI38, UFPI59), one strain of reference to Phaseolus vulgaris (CIAT899) and two controls (with and without nitrogen). The parameters of nodulation, N accumulation and yield varied between treatments and locations. The nodule biomasses were higher in UFPI59 and UFPI32 (Piauí), and CIAT899 and UFPI32 (Ceará). The highest values of nodule size were found in treatments UFPI59 in both locations. Lima bean presented highest values of leaf N in UFPI59 and CIAT899. The highest values of grain yield were found in the treatment UFPI59 as compared to CIAT899 and the controls. The results confirmed the potential of UFPI59 in promoting nodulation, $\mathrm{N}$ accumulation, plant growth and yield of lima bean in both locations.
\end{abstract}

Keywords: Phaseolus lunatus; biological N fixation; Rhizobium; inoculation

\section{INTRODUCTION}

Lima bean (Phaseolus lunatus) is an important legume crop cultivated in some countries of North, Central and South America (Amorim et al., 2019), representing a substantial source of protein (Araujo et al., 2015). In addition, lima bean presents high rusticity and capacity to withstand long dry periods similar those found in the Northeastern region of Brazil (Santos et al., 2011). Indeed, lima bean is cultivated by smallholder farms from the Northeastern region of Brazil, mainly the states of Piauí and Ceará, where the crop yield is estimated in 0.45 ton ha $^{-1}$ (IBGE, 2018). Despite of its importance, lima bean yet presents low production and one reason is the low $\mathrm{N}$ availability in soil.

However, lima bean is a $\mathrm{N}$-fixing crop and this characteristic can increase its growth and yield (Amorim et al., 2019). Thus, the biological $\mathrm{N}$ fixation (BNF) is an important process that can increase the lima bean yield (Lopes et al., 2015). Indeed, previous studies, under greenhouse conditions, have reported $\mathrm{N}$-fixing rhizobia contributing, through BNF, to the growth of lima bean (Costa Neto et al., 2017; Amorim et al., 2019).

The responses of plants to BNF varies according to the rhizobia (Cardoso et al., 2017) and their growing region (Leggett et al., 2017). Thus, rhizobia isolated from a region and adapted to its specific soil conditions need to be evaluated in different locations and conditions, such as temperature, chemical properties and population of native bacteria (Koskey et al., 2017; Irisarri et al., 2019). It is important since indication of potential rhizobia should considerate their efficiency in different regions and soil conditions. So far, the studies evaluating potential $\mathrm{N}$-fixing rhizobia are concentrated to soybean, common bean and cowpea (Merkeb et al., 2016; Pinto et al., 2007; Batista et al., 2017), while there are not studies with lima bean, mainly

\footnotetext{
Submitted on May $18^{\text {th }}, 2020$ and accepted on July $21^{s t}, 2020$

${ }^{1}$ This work belongs to the Doctoral Thesis of the first author

${ }^{2}$ Universidade Federal do Piauí, Centro de Ciências Agrárias, Laboratório de Qualidade de Solos, Teresina, Piauí, Brazil. claudyannecosta@hotmail.com; jadsonantunes2016@gmail.com; ademir@ufpi.edu.br

${ }^{3}$ Universidade Federal do Piauí, Centro de Ciências Agrárias, Departamento de Fitotecnia, Teresina, Piauí, Brazil. acalopes@ufpi.edu.br

${ }^{4}$ Universidade Federal Rural de Pernambuco, Recife, Pernambuco, Brazil. anadoloressantiagodefreitas@ gmail.com

*Corresponding author: ademir@ufpi.edu.br
} 
under field conditions in different regions. As consequence, lima bean does not have any recommended rhizobia for inoculation, being necessary to advance the studies for selecting rhizobia to this crop.

Therefore, it is necessary and important the searching of suitable agricultural practices to increase the lima bean yield. The optimization of BNF, by the selection of efficient $\mathrm{N}$-fixing rhizobia, could contribute for increasing the lima bean yield. Thus, the aim of this field study was to evaluate the potential of rhizobia in increasing the lima bean yield in two regions from Piaui and Ceará states.

\section{MATERIAL AND METHODS}

The experiments were simultaneously conducted at Piauí and Ceará states, Brazil, from May through September 2019. In Piauí state, the experiment was conducted in the Experimental Field from Universidade Federal do Piauí, Teresina $\left(05^{\circ} 05^{\prime} 21\right.$ "S; $\left.42^{\circ} 48^{\prime} 07^{\prime \prime} \mathrm{W}\right)$ under a mean of temperature of $28{ }^{\circ} \mathrm{C}$ and $70 \%$ of humidity. In Ceará, the experiment was conducted at Instituto Federal do Ceará, Tiangua $\left(3^{\circ} 43^{\prime} 55^{\prime \prime} \mathrm{S} ; 4^{\circ} 0^{\prime} 45 \mathrm{~W}\right)$ under a mean of temperature of $22{ }^{\circ} \mathrm{C}$ and $81 \%$ of humidity. The soils from Piauí and Ceará were classified as Fluvic and Quartzarenic Neosols, respectively, and the chemical properties (0-20 $\mathrm{cm})$ are shown in Table 1. Particularly, soil from Ceará presented low soil $\mathrm{pH}$ (5.0) and it was corrected by using $650 \mathrm{~kg} \mathrm{ha}^{-1}$ of dolomitic lime $(17 \% \mathrm{CaO}$ and $13 \% \mathrm{MgO})$ that was applied uniformly on the soil surface. The rate was calculated according to Bezerra et al. (2010).

Six treatments were compared under a randomized block design with four replicates. The treatments consisted of three rhizobia UFPI32 (Bradyrhizobium sp.), UFPI38 (Rhizobium sp.) and UFPI-59 (Bradyrhizobium sp.), isolated in soils from Piauí state (Antunes et al., 2011) and selected from previous studies under greenhouse conditions. These rhizobia One strain of reference to Phaseolus vulgaris (CIAT899; Rhizobium tropici) and two controls $(\mathrm{PC}-$ with $\mathrm{N} ; \mathrm{NC}-$ without $\mathrm{N})$. The strains

All strains were grown in Erlenmeyer flasks containing $50 \mathrm{~mL}$ of liquid culture broth (under orbital shaking at 200 $\mathrm{rpm}, 28^{\circ} \mathrm{C}, 72 \mathrm{~h}$ ). The bacterial growth was verified through a spectrophotometer (wavelength of $540 \mathrm{~nm}$ ) considering a final concentration of $10^{9} \mathrm{CFU} \mathrm{mL}^{-1}$. Seeds of lima bean, genotype UFPI480, were disinfested with alcohol (70\%) for 30 seconds and sodium hypochlorite (2\%) for 60 seconds, being washed five times with sterile distilled water. Afterwards, seeds were inoculated (in the inoculated treatments) and sowed, immediately, in plots with $30 \mathrm{~m}^{2}$ each, with $20 \mathrm{~m}^{2}$ of usable area for analysis, and rows are spaced $1.0 \mathrm{~m}$ apart. In each row, plants were spaced $1.0 \mathrm{~m}$ between them which provides a total of 10000 plants per hectare. The positive control $(+\mathrm{N})$ received $20 \mathrm{~kg} \mathrm{ha}^{-1} \mathrm{~N}$ (100 $\mathrm{kg} \mathrm{ha}^{-1} \mathrm{NH}_{4} \mathrm{SO}_{4}$ ) at sowing. All plots received chemical fertilization with $\mathrm{P}\left(60 \mathrm{~kg} \mathrm{ha}^{-1} \mathrm{P}_{2} \mathrm{O}_{5}\right)$ and $\mathrm{K}\left(30 \mathrm{~kg} \mathrm{ha}^{-1} \mathrm{~K}_{2} \mathrm{O}\right)$. In both locations, lima bean was grown under rainfed conditions.

At 45 days after sowing (flowering stage), five plants from each plot were collected and excised at the cotyledonal node to separate shoots from roots. In the flowering stage, lima bean presents the highest number of active nodules (Santos et al., 2009). Nodules were separates from the roots and counted to determine nodule number $(\mathrm{NN})$. Afterward, nodules, shoots and roots were dried $\left(65^{\circ} \mathrm{C} ; 72 \mathrm{~h}\right)$ and weighed to determine nodules (NDW), shoot (SDW) and roots (RDW) dry weight. Nodules size (NS) was estimated by using the ratio between NDW and NN, expressed as mg per nodule (Rocha et al., 2019). Total $\mathrm{N}$ in plant was estimated by by Kjedahl method. At 70 days, lima bean yield was evaluated by sampling of five plants inside the plots and grains were dried for $13 \%$.

The normality of data was analyzed by using the test of Shapiro-Wilk and treatments were assessed in two locations (Piauí and Ceará). Afterward, data were statistically analyzed by using ANOVA, and the means were compared using Scott-Knott test $(p \leq 0.05 \%)$.

\section{RESULTS AND DISCUSSION}

Lima bean grown in Ceará showed the highest and lowest values of NN and NDW with CIAT899 and NC, respectively (Table 2). However, the inoculation of UFPI32 promoted similar value of NDW in lima bean as compared to CIAT899. Although CIAT899 has promoted higher NN and NDW in lima bean grown in Ceará, the value of NS was highest with UFPI59. Regarding to lima bean growth, the values of SDW and RDW presented small variation between treatments (Table 2). Thus, PC presented the highest values of SDW, being similar to UFPI32, UFPI59 and CIAT899, and higher than UFPI38 and NC. In contrast, UFPI32 promoted the highest RDW, being similar

Table 1: Chemical properties of the soils used in this study

\begin{tabular}{|c|c|c|c|c|c|c|}
\hline & $\mathrm{pH}$ & OM & $\mathbf{P}$ & $\mathbf{K}$ & $\mathrm{Ca}$ & Mg \\
\hline & $\left(\mathrm{H}_{2} \mathrm{O}\right)$ & $\left(\mathrm{g} \mathrm{kg}^{-1}\right)$ & \multicolumn{2}{|c|}{$\left(\mathrm{mg} \mathrm{kg}^{-1}\right)$} & \multicolumn{2}{|c|}{$\left(\mathrm{cmol}_{\mathrm{c}} \mathrm{kg}^{-1}\right)$} \\
\hline$\overline{\text { Ceará }}$ & 6.0 & 17.0 & 0.7 & 19.5 & 1.2 & 0.5 \\
\hline Piauí & 6.5 & 8.3 & 0.5 & 15.6 & 1.3 & 0.7 \\
\hline
\end{tabular}

$\mathrm{OM}$ - organic matter

Rev. Ceres, Viçosa, v. 67, n.5, p. 419-423, sep/oct, 2020 
to UFPI38, UFPI59, CIAT899 and PC, and different than NC. The inoculation of UFPI59 and CIAT899 promoted the highest accumulation of $\mathrm{N}$ in lima bean as compared to the other treatments (Table 2).

The values of NN did not vary between treatments in lima bean grown in Piauí, while that the inoculation of UFPI59 and UFPI32 promoted higher values of NDW (Table 3). Interestingly, the value of NS was found in lima bean inoculated with UFPI59. Lima bean grown in Piauí presented the highest values of SDW with the inoculation of UFPI38 and UFPI59 (Table 3). However, the highest values of RDW were found in lima bean inoculated with UFPI32 and UFPI59. Regarding to leaf N, the highest values were observed with the inoculation of UFPI59 and CIAT899.

The highest values of grain yield were found in lima bean inoculated with UFPI59 as compared to CIAT899, PC and NC in both Ceará and Piauí state (Table 4). In addition, the inoculation of UFPI38 also contributed to increase the grain yield as compared to $\mathrm{PC}$ and $\mathrm{NC}$ in both states.

In this study, four potential rhizobia strains to lima bean inoculation were evaluated under field conditions in both Ceará and Piauí states. These strains were compared against a strain of reference to commom bean (CIAT899) and two controls ( $\mathrm{NC}$ and $\mathrm{PC}$ ). Although both states were not statistically compared, the results showed higher nodulation in Ceará than Piauí, and it can be explained for the lowest soil temperature found in Ceará that contributed for a better environment to rhizobia.
Anyway, the results showed different responses to nodulation, i.e. nodule number and dry weight, in lima bean grown in Ceará and Piauí. In Ceará, CIAT899 stimulated a greater number of nodule than other rhizobia, and it suggest that the rhizobia from Piauí (UFPI32, UFPI38, UFPI59) do not present efficiency in stimulating nodulation in lima bean in Ceará. However, UFPI32 promoted similar values of nodule biomass as compared to CIAT899 in lima bean grown in Ceará. Since nodule biomass and size are the most important parameters to estimate the efficiency of BNF in comparison to nodule number (Oðutcu et al., 2010), these results suggest potential efficiency of UFPI32 in nodulating lima bean in Ceará.

On the other hand, UFPI59 presented better performance in increasing the nodule size in lima bean in both states. The better performance of UFPI-59 in stimulating larger nodules could be important to increase the biological $\mathrm{N}$ fixation, since higher nodules contribute

Table 4: Values of yield $\left(\mathrm{kg} \mathrm{ha}^{-1}\right)$ of lima bean inoculated with rhizobia and grown in Piauí and Ceará states. At 70 days of lima bean sowing

\begin{tabular}{lrr}
\hline & Ceará & Piauí \\
\hline UFPI32 & $437^{\mathrm{c}}$ & $816^{\mathrm{b}}$ \\
UFPI38 & $801^{\mathrm{ab}}$ & $998^{\mathrm{ab}}$ \\
UFPI59 & $1005^{\mathrm{a}}$ & $1150^{\mathrm{a}}$ \\
CIAT899 & $410^{\mathrm{c}}$ & $758^{\mathrm{b}}$ \\
PC & $650^{\mathrm{b}}$ & $350^{\mathrm{c}}$ \\
NC & $400^{\mathrm{c}}$ & $175^{\mathrm{c}}$ \\
\hline
\end{tabular}

PC - positive control; NC- negative control;

Table 2: Values of NN (nodule $\left.\mathrm{l}^{-1}\right)$, NDW $\left(\mathrm{mg} \mathrm{pl}^{-1}\right)$, NS (mg nodule $\left.{ }^{-1}\right)$, SDW $\left(\mathrm{g} \mathrm{pl}^{-1}\right)$, RDW $\left(\mathrm{g} \mathrm{pl}^{-1}\right)$, and leaf $\mathrm{N}(\%)$ in lima bean inoculated with rhizobia and grown in Ceará state. At 45 days of lima bean sowing

\begin{tabular}{lcccccc}
\hline & NN & NDW & NS & SDW & RDW & Leaf N \\
\hline UFPI32 & $150^{\mathrm{b}}$ & $144^{\mathrm{ab}}$ & $1.2^{\mathrm{b}}$ & $2.2^{\mathrm{ab}}$ & $2.3^{\mathrm{a}}$ & $1.3^{\mathrm{b}}$ \\
UFPI38 & $153^{\mathrm{b}}$ & $109^{\mathrm{c}}$ & $0.9^{\mathrm{b}}$ & $1.4^{\mathrm{b}}$ & $2.0^{\mathrm{ab}}$ & $1.4^{\mathrm{b}}$ \\
UFPI59 & $148^{\mathrm{b}}$ & $94^{\mathrm{c}}$ & $1.5^{\mathrm{a}}$ & $1.8^{\mathrm{ab}}$ & $1.9^{\mathrm{ab}}$ & $1.8^{\mathrm{a}}$ \\
CIAT899 & $239^{\mathrm{a}}$ & $157^{\mathrm{a}}$ & $0.7^{\mathrm{b}}$ & $2.2^{\mathrm{ab}}$ & $2.0^{\mathrm{ab}}$ & $1.9^{\mathrm{a}}$ \\
PC & $147^{\mathrm{b}}$ & $132^{\mathrm{b}}$ & $0.9^{\mathrm{b}}$ & $2.4^{\mathrm{a}}$ & $1.8^{\mathrm{ab}}$ & $1.2^{\mathrm{b}}$ \\
NC & $39^{\mathrm{c}}$ & $42^{\mathrm{a}}$ & $1.0^{\mathrm{b}}$ & $1.4^{\mathrm{b}}$ & $0.8^{\mathrm{c}}$ & $1.4^{\mathrm{b}}$ \\
\hline
\end{tabular}

PC - positive control; NC- negative control

Table 3: Values of NN (nodule $\left.\mathrm{pl}^{-1}\right)$, NDW $\left(\mathrm{mg} \mathrm{pl}^{-1}\right)$, NS $\left(\right.$ mg nodule $\left.{ }^{-1}\right)$, SDW $\left(\mathrm{g} \mathrm{pl}^{-1}\right)$, RDW $\left(\mathrm{g} \mathrm{pl}^{-1}\right)$, and leaf $\mathrm{N}(\%)$ in lima bean inoculated with rhizobia and grown in Piaui state. At 45 days of lima bean sowing

\begin{tabular}{lcccccc}
\hline & NN & NDW & NS & SDW & RDW & Leaf N \\
\hline UFPI32 & $17^{\mathrm{a}}$ & $66^{\mathrm{a}}$ & $3.5^{\mathrm{b}}$ & $2.9^{\mathrm{b}}$ & $4.3^{\mathrm{a}}$ & $1.8^{\mathrm{c}}$ \\
UFPI38 & $10^{\mathrm{a}}$ & $25^{\mathrm{b}}$ & $2.3^{\mathrm{c}}$ & $4.9^{\mathrm{a}}$ & $2.1^{\mathrm{b}}$ & $2.5^{\mathrm{b}}$ \\
UFPI59 & $18^{\mathrm{a}}$ & $74^{\mathrm{a}}$ & $4.6^{\mathrm{a}}$ & $4.5^{\mathrm{a}}$ & $3.5^{\mathrm{a}}$ & $3.4^{\mathrm{a}}$ \\
CIAT899 & $13^{\mathrm{a}}$ & $10^{\mathrm{b}}$ & $0.7^{\mathrm{b}}$ & $3.0^{\mathrm{b}}$ & $2.1^{\mathrm{b}}$ & $3.3^{\mathrm{a}}$ \\
PC & $15^{\mathrm{a}}$ & $11^{\mathrm{b}}$ & $0.6^{\mathrm{b}}$ & $3.1^{\mathrm{b}}$ & $2.2^{\mathrm{b}}$ & $1.6^{\mathrm{c}}$ \\
NC & $9^{\mathrm{a}}$ & $25^{\mathrm{b}}$ & $2.4^{\mathrm{c}}$ & $2.8^{\mathrm{b}}$ & $2.5^{\mathrm{b}}$ & $1.9^{\mathrm{c}}$ \\
\hline
\end{tabular}

PC - positive control; NC- negative control 
with more $\mathrm{N}$ fixed in the whole root system (Tajima et al., 2007). For instance, previous studies have reported that soybean presenting larger nodules exhibits high $\mathrm{N}$ fixation as compared to plants with smaller nodules (Sato et al., 2003; Yashima et al., 2003). Interestingly, UFPI59 has been recognized as potential in a previous study with lima bean under laboratory and greenhouse conditions (Antunes et al., 2011). In addition, this strain, classified as Bradyrhizobium sp., presents interesting biochemical features, i.e. it is positive for catalase, gelatinase and solubilization of $\mathrm{P}$ (Chibeba et al., 2020).

Indeed, UFPI59 contributed for increasing the $\mathrm{N}$ content in lima bean and it can be correlated to the higher nodule size found with this strain. There is a strong correlation between nodule size and $\mathrm{N}$ accumulation in plants (Delix $e t$ al., 2010; Voisin et al., 2015; Hamawaki \& Kantartzi, 2018) and it corroborates with the results observed in this study. It can indicate that UFPI59 presents high effectiveness in contributing with $\mathrm{N}$ to lima bean. Previously, Antunes et al. (2011) also found UFPI59 increasing $\mathrm{N}$ accumulation in lima bean under laboratory conditions.

Regarding to lima bean growth, the results showed variation between treatments and it can suggest that shoot and root biomass could not be suitable parameters to evaluate rhizobia strain in lima bean. Anyway, UFPI59 promoted high values of shoot and root dry weight in lima bean. In line with the results found on nodule size and $\mathrm{N}$ accumulation, the inoculation of UFPI59 promoted the higher grain yield in lima bean. This grain yield is about twice as high as the average found in Ceará and Piauí states (IBGE, 2018). Thus, UFPI59 seems to present potential to be recommended as inoculant to lima bean. The results also showed lower grain yield in soil without fertilization and even in in fertilized plots, and these values are within the range found in previous studies with lima bean (Santos et al., 2002; Oliveira et al., 2011).

Finally, this study showed that, in general, nodules and plant parameters varied between Ceará and Piauí states. It means that there were differences in the responses of lima bean according to rhizobia and location. These differences between rhizobia on all evaluated parameters agree with some studies with cowpea (Farias et al., 2016), soybean (Barbosa et al., 2017) and common bean (Mercante et al., 2017). Regarding to location, the results showed that lima bean presented better growth and yield in Piauí than Ceará, and it can be explained due to the genotype of lima bean used in this study is originated from Piauí, and it contributed for the better performance of this state crop. Anyway, the results have shown that UFPI59 presents high potential to be recommended as inoculant to lima bean in Ceará and Piauí. However, further studies should be done to evaluate this strain under different $\mathrm{N}$ rates, lima bean genotypes, and at least for two years.

\section{CONCLUSIONS}

The strain UFPI59, classified as Bradyrhizobium sp., promotes larger nodules, higher $\mathrm{N}$ accumulation and plant growth in lima bean. In addition, this strain increases the grain yield of lima bean in both Ceará and Piauí states which indicates this bacterium as a potential candidate to be recommended to inoculation in lima bean for the states of Piauí and Ceará. It is important to lima bean producers that can be benefited with higher grain yield through of a sustainable and biological technology.

\section{ACKNOWLEDGEMENTS, FINANCIAL SUPPORT AND FULL DISCLOSURE}

The authors thanks Coordenação de Aperfeiçoamento de Pessoal de Nivel Superior (CAPES) for the Doctor's scholarship to the first author, and Conselho Nacional de Desenvolvimento Cientifico e Tecnológico (CNPq) for the fellowship of Research to Ademir S. F. Araujo, Angela C. A. Lopes and Ana Dolores S. Freitas. The authors inform that there is no conflict of interests in carrying out the research and publishing this manuscript.

\section{REFERENCES}

Amorim MR, Antunes JEL, Oliveira LMS, Rocha SMB, Aquino JPA, Figueiredo MVB \& Araújo ASF (2019) Current knowledge and future prospects of lima bean (Phaseolus lunatus)-rhizobia symbiosis. Revista de la Faculdad de Ciências Agrárias, 5:280288 .

Antunes JEL, Gomes RLF, Lopes ACA, Araújo ASF, Lyra MCCP \& Figueiredo MVB (2011) Eficiência simbiótica de isolados de rizóbio noduladores de feijão-fava (Phaseolus luntaus L.). Revista Brasileira de Ciência do Solo, 35:751-757.

Araujo ASF, Lopes ACA, Gomes RLF, Beserra Junior JEA, Antunes JEL \& Figueiredo MVB (2015) Diversity of native rhizobia nodulating Phaseolus lunatus in Brazil. Legume Research, 38:653-657.

Barbosa LP, Costa PF, Ribeiro PRA, Rufini M, Guimarães AA \& Moreira FMS (2017) Symbiotic efficiency and genotypic characterization of variants of Bradyrhizobium spp. in commercial inoculants for soybeans. Revista Brasileira de Ciência do Solo, 41:e0160572.

Batista ER, Guimarães SL, Bonfim-Silva EM \& Souza CPA (2017) Combined inoculation of rhizobia on the cowpea development in the soil of Cerrado. Revista Ciência Agronômica, 48:745-755.

Bezerra BR, Araújo ASF, Santos JA \& Carneiro RFV (2010) Fertilidade do Solo e Adubação. In: Lopes ACA, Gomes RLF \& Araujo ASF (Eds.) A cultura do feijão-fava no meio norte do Brasil. Teresina, Edufpi. p.129-138.

Cardoso AA, Andraus MP, Borba TCO, Martin-Didonet CCG \& Ferreira EPB (2017) Characterization of rhizobia isolates obtained from nodules of wild genotypes of common bean. Brazilian Journal of Microbiology, 48:43-50.

Chibeba AM, Pereira CS, Antunes JEL, Ribeiro RA, Lopes ACA, Gomes RLF, Hungria M \& Araújo ASF (2020) Polyphasic characterization of nitrogen-fixing and co-resident bacteria in nodules of Phaseolus lunatus inoculated with soils from Piauí State, Northeast Brazil. Symbiosis, 80:279-292. 
Costa Neto VP, Mendes JBS, Araújo ASF, Alcântara Neto F, Bonifacio A \& Rodrigues AC (2017) Symbiotic performance, nitrogen flux and growth of lima bean (Phaseolus lunatus L.) varieties inoculated with different indigenous strains of rhizobia. Symbiosis, 73:117-124.

Deliæ D, Stajkoviæ O, Rasuliæ N, Kuzmanoviæ D, Jošiæ D \& Milièiæ B (2010) Nodulation and $\mathrm{N}_{2}$ Fixation Effectiveness of Bradyrhizobium Strains in Symbiosis with Adzuki Bean, Vigna angularis. Brazilian Archives of Biology and Technology, 53:293-299.

Farias TP, Soares BL, Araújo ARA \& Moreira FMS (2016) Symbiotic efficiency of rhizobia strains with cowpea in Southern Maranhão. Revista Caatinga, 29:611-618.

Hamawaki RL \& Kantartzi SK (2018) Di-nitrogen fixation at the early and late growth stages of soybean. Acta Scientiarum Agronomy, 40:e36372.

IBGE (2018) Produc'aPo agriìcola municipal: culturas temporaìrias e permanentes. Available at: https://sidra.ibge.gov.br/tabela/5457. Accessed on: February $10^{\text {th }}, 2020$.

Irisarri P, Cardozo G, Tartaglia C, Reyno R, Gutiérrez P, Lattanzi FA, Rebuffo M \& Monza J (2019) Selection of Competitive and Efficient Rhizobia Strains for White Clover. Frontiers in Microbiology, 10:768.

Koskey G, Mburu SW, Njeru EM, Kimiti JM, Ombori O \& Maingi JM (2017) Potential of Native Rhizobia in Enhancing Nitrogen Fixation and Yields of Climbing Beans (Phaseolus vulgaris L.) in Contrasting Environments of Eastern Kenya. Frontiers in Plant Science, 8:443.

Leggett M, Diaz-Zorita M, Koivunen M, Bowman R, Pesek R, Stevenson C \& Leister T (2017) Soybean response to inoculation in the United States and Argentina. Agronomy Journal, 109:1031-1038.

Lopes ÂCA, Gomes RLF \& Araújo ASF (2015) Phaseolus lunatus: diversity, growth and production. New York, Nova Science Publishers. $177 \mathrm{p}$.

Mercante FM, Otsubo AA \& Brito OR (2017) New Native Rhizobia Strains for Inoculation of Common Bean in the Brazilian Savanna. Revista Brasileira de Ciência do Solo, 41:e0150120.

Merkeb F, Redi M \& Gebremedhin W (2016) Evaluation of Different Commercial Rhizobial Strains on Soybean (Glycine max L.) Yield at Pawe District, Northwestern Ethiopia. World Scientific News, 55:15-26.
Oðutcu H, Kasimoðlu C \& Elkoca E (2010) Effects of rhizobium strains isolated from wild chickpeas on the growth and symbiotic performance of chickpeas (Cicer arietinum L.) under salt stress Turkish. Journal of Agriculture and Forestry, 34:361-371.

Oliveira FN, Torres SB \& Benedito CP (2011) Caracterização botânica e agronômica de acessos de feijão fava, em Mossoró, RN. Revista Caatinga, 24:143-148.

Pinto FGS, Hungria M \& Mercante FM (2007) Polyphasic characterization of Brazilian Rhizobium tropici strains effective in fixing $\mathrm{N}_{2}$ with common bean (Phaseolus vulgaris L.). Soil Biology \& Biochemistry, 39:1851-1864.

Rocha SMB, Antunes JEL, Silva AVCR, Oliveira LMS, Aquino JPA, Melo WJ, Figueiredo MVB \& Araújo ASF (2019) Nodulation, nitrogen uptake and growth of lima bean in a composted tannery sludge-treated soil. Ciência Rural, 49:e20190301.

Santos D, Corlett FMF, Mendes JEMF \& Wanderley Júnior JSA (2002) Produtividade e morfologia de vagens e sementes de variedades de fava no Estado da Paraíba. Pesquisa Agropecuária Brasileira, 37:1407-1412.

Santos JO, Araújo ASF, Gomes Ferreira RL, Lopes ACA \& Figueiredo MVB (2009) Ontogenia da nodulação em feijão-fava (Phaseolus lunatus). Revista Brasileira de Ciências Agrárias, 4:426-429.

Santos JO, Antunes JEL, Araújo ASF, Lyra MCCP, Gomes RLF, Lopes ACA \& Figueiredo MVB (2011) Genetic diversity among native isolates of rhizobia from Phaseolus lunatus. Annals of Microbiology, 61:437-444.

Sato T, Kaneta Y, Fukuta N, Kobayashi H, Shindo H, Ota T \& Sato A (2003) Effect of soil physical properties on soybean nodulation and $\mathrm{N}_{2}$ fixation at the early growth stage in heavy soil field in Hachirogata polder, Japan. Soil Science and Plant Nutrition, 49:695-702.

Voisin AS, Prudent M, Duc G \& Salon C (2015) Pea nodule gradients explain $\mathrm{N}$ nutrition and limited symbiotic fixation in hypernodulating mutants. Agronomy for Sustainable Development, 35:1529-1540.

Tajima R, New Lee NO, Abe J, Lux A \& Morita S (2007) NitrogenFixing Activity of Root Nodules in Relation to Their Size in Peanut (Arachis hypogaea L.). Plant Production Science, 10:423-429.

Yashima H, Fujikake H, Sato T, Ohtake N, Sueyoshi K \& Ohyama $\mathrm{T}$ (2003) Systemic and local effects of long-term application of nitrate on nodule growth and $\mathrm{N}_{2}$ fixation in soybean (Glycine $\max$ [L.] Merr.). Soil Science Plant Nutrition, 49:825-834. 